DOI: $10.15290 /$ bsl.2017.11.04

\author{
Agnieszka Izdebska \\ Wydział Filologiczny \\ Uniwersytet Łódzki \\ e-mail: agnieszka.izdebska@uni.lodz.pl
}

\title{
„Tu wszędzie jest Rzym" - przestrzeń w kryminałach historycznych Stevena Saylora, Johna Maddoxa Robertsa i Lindsey Davis
}

Większość krytyków piszących o kryminale historycznym uważa go za formę hybrydyczną, zawierającą w sobie zarówno elementy powieści historycznej, jak i kryminalnej. Ta dwoistość gatunkowa przekłada się, między innymi, na różne lokowanie tej konwencji w obrębie genologii: postrzegana jest albo jako wariant powieści historycznej, albo kryminalnej. Przeważa jednak pogląd, że jest to odmiana drugiej $\mathrm{z}$ nich ${ }^{1}$, a definiuje się ją jako powieść kryminalną, w której fabuła, zbudowana wokół intrygi kryminalnej, osadzona jest $\mathrm{w}$ czasie - z perspektywy doświadczenia autora - historycznym $^{2}$. Fakt, iż dla niektórych kryminał historyczny to subgatunek powieści historycznej ${ }^{3}$, uwypukla istotny, problematyczny element konwencji: kwestię sposobu prezentacji przeszłości historycznej oraz funkcję, jaką zdarzenia historyczne pełnią w konstrukcji fabuły. Generalnie rzecz ujmując, w obrębie

1 Zob. na przykład P. Kaczyński, Kryminał historyczny - próba poetyki, w: Literatura kryminalna. Śledztwo w sprawie gatunków, red. A. Gemra, Kraków 2014, s. 191; K. Dominas, Antyk w kryminale, kryminat w antyku. Steven Saylor i recepcja literatury antycznej, w: Literatura kryminalna. Na tropie źródet, red. A. Gemra, Kraków 2015, s. 221; R.W. Winks, Preface, w: The Detective as Historian: History and Art in Historical Crime Fiction, ed. R.B. Browne i L.A. Kreiser, Jr, Bowling Green, 2000, s. ix.

2 Zob. A. Izdebska, hasło: kryminat historyczny, "Zagadnienia Rodzajów Literackich" 2016, t. 59 , z. 4 (120).

3 Zob. na przykład F.A. Salamone, Maan Meyers: The Saga of Dutchman, w: The Detective as Historian..., s. 160; też D. Bradshaw Smith, Bruce Alexander: Sir Henry Fielding and Blind Justice, w: The Detective as Historian..., s. 175. 
tej konwencji mamy do czynienia zarówno z takimi opowieściami, w których zdarzenia te są równie ważne, co intryga kryminalna, jak i traktującymi historię jako mniej lub bardziej istotne tło.

Wszystkie komplikacje teoretyczne związane z kryminalną powieścią historyczną można zilustrować przy okazji analizy trzech serii amerykańskich kryminałów, których akcja rozgrywa się w starożytnym Rzymie, aczkolwiek nie ta kwestia będzie zasadniczym tematem tego tekstu. Pierwszy cykl, autorstwa Johna Maddoxa Robertsa, nosi tytuł $S P Q R^{4}$ (to skrót określenia państwa rzymskiego - Senatus Populusque Romanus - widniejący, między innymi, na legionowych znakach). Opowieści głównej postaci serii, detektywa-amatora Decjusza Metellusa Młodszego, spisywane przez niego samego w okresie panowania Oktawiana Augusta, sięgają 55 r. p.n.e. - roku konsulatu Pompejusza i Krassusa. Akcja serii Roma Sub Rosa ${ }^{5}$ Stevena Saylora toczy się niemal w tym samym czasie: zaczyna się w okresie dyktatury Sulli, w 80 r. p.n.e., kończy tuż przed zabójstwem Juliusza Cezara. Gordianus, bohater powieści Saylora, zwany Poszukiwaczem, zarabia na życie rozwikływaniem rzymskich kryminalnych tajemnic. Zdarzenia opisane w powieściach Lindsey Davis o Marku Dydiuszu Falconie ${ }^{6}$ rozgrywają się później niż poprzednie, za panowania cesarza Wespazjana, w okolicach 70 r. n.e. Z punktu widzenia zasygnalizowanych wyżej komplikacji związanych z hybrydycznością gatunku cykl Say-

4 W polskim tłumaczeniu ukazało się zaledwie kilka powieści cyklu: Śledztwo Decjusza, przeł. E. Wierzbicka, Bellona, Warszawa 2012; Spisek Katyliny, przeł. E. Wierzbicka, Bellona, Warszawa 2012; Świętokradztwo na misteriach, przeł. E. Wierzbicka, Bellona, Warszawa 2012; Detektyw Cezara, przeł. E. Wierzbicka, Bellona, Warszawa 2014; Świątynia muz, przeł. E. Wierzbicka, Bellona, Warszawa 2014; Saturnalia, przeł. E. Wierzbicka, Bellona, Warszawa 2014.

5 Polskie tłumaczenia tych powieści ukazały się w Domu Wydawniczym "Rebis” i zostały zebrane w pięciu tomach: Zagadki Gordianusa, przeł. J. Szczepański, Poznań 2011; Przygody Gordianusa, przeł. J. Szczepański, Poznań 2012; Historie Gordianusa, przeł. J. Szczepański, Poznań 2013; Tajemnice Gordiadusa, przeł. J. Szczepański, Poznań 2013; Ostatnie sprawy Gordiadusa, przeł. J. Szczepański, Poznań 2013. W posłowiu do pierwszej powieści cyklu Saylor wyjaśnia, skąd wziął się tytuł serii: „W starożytnym Egipcie róża była symbolem Horusa, utożsamianego później przez Greków i Rzymian z bogiem milczenia. Rozwinął się zwyczaj zawieszania róży nad stołem radnych na znak, że wszyscy obecni zobowiązani są do dochowania tajemnicy. Zwrot sub rosa (pod różą) przyjął się jako określenie wszystkiego, co się robi w sekrecie. Stąd mój tytuł Roma sub rosa, czyli historia sekretów Rzymu, które widzimy oczami Gordianusa Poszukiwacza" [S. Saylor, Dom westalek, w: tegoż, Zagadki Gordianusa, s. 666].

6 Tylko kilka powieści serii ukazało się w polskim przekładzie w Domu Wydawniczym „Rebis": Srebrne świnki, przeł. K. Majchrzak, Poznań 2009; Wykute w brązie, przeł. K. Majchrzak, Poznań 2009; Miedziana Wenus, przeł. K. Majchrzak, Poznań 2009; Żelazna ręka Marsa, przeł. K. Majchrzak, Poznań 2010; Złoto Posejdona, przeł. K. Majchrzak, Poznań 2010; Ostatni akt w Palmirze, przeł. K. Majchrzak, Poznań 2011. Davis napisała również kryminały, których bohaterką jest adoptowana córka Falkona, Flawia Alba, tak jak ojciec prowadząca śledztwa, jednak żadna $\mathrm{z}$ tych powieści nie została dotychczas przetłumaczona na język polski. 
lora lokuje się najbliżej konwencji powieści historycznej ${ }^{7}$, zaś utwory Davis są przede wszystkim znakomitą realizacją modelu powieści detektywistycznej w wersji amerykańskiej, hard-boiled ${ }^{8}$. Gdy zestawiać $S P Q R$ z powieściami Saylora, łatwo dostrzec podobieństwa wynikające choćby z faktu ulokowania fabuł obu cyklów w okresie schyłku republiki. Stąd podobne rozpoznania obu głównych postaci. Gordianus pisze: „Republika złożona była ciężką chorobą, być może śmiertelną. Jej drgawki były widowiskiem, na jakie nie mogłem wprost patrzeć, ale jeszcze trudniej było mi oderwać od nich wzrok" . Zaś Decjusz Mercellus notuje: „my Rzymianie, sami dostarczamy sobie wrogów [...] teraz, gdy patrzę na wszystko z perspektywy czasu, dostrzegam, że było to ostatnie lato starej republiki, która umarła tej jesieni" ${ }^{10}$. Gordianus drży o życie Cezara, którego dążenie do władzy dyktatorskiej nie budzi jego sympatii, ale uważa go za człowieka chroniącego państwo przed kolejnym okresem chaosu, zaś bohater Robertsa pisze z perspektywy nowego porządku, który po śmierci Gajusza Juliusza został zbudowany i którego doświadczył. Jednak obaj detektywi wiedzą, że są świadkami końca świata, który dotąd znali.

Nawiasem mówiąc, kwestia ogromnej popularności tego okresu rzymskiej historii (tzn. schyłku republiki i początków cesarstwa) we współczesnych opowieściach literackich i filmowych ${ }^{11}$ jest tyleż pochodną ekscytują-

7 W posłowiu do pierwszej powieści cyklu Saylor pisze: „Czytelnicy powieści historycznych, którzy mają zwyczaj zaczynać lekturę od posłowia, powinni wiedzieć, że Rzymska krew jest też zagadką kryminalną" [S. Saylor, Rzymska krew, w: tegoż Zagadki Gordianusa, s. 400]. To zdanie sugeruje, że dla autora osadzenie powieści w konkretnych realiach historycznych ma znaczenie nadrzędne wobec konstruowania intrygi kryminalnej. Powieść w dużej mierze inspirowana jest zresztą jedną z mów obrończych Cycerona: akcja dotyczy sprawy Sekstusa Roscjusza oskarżonego o zlecenie zabójstwa swego ojca. Jak w przypadku wszystkich swoich powieści, tak i tu Saylor w cytowanej już nocie od autora podaje źródła, z których korzystał, poddając je krytycznej analizie: „Poważną wątpliwość na przykład budzi kwestia, czy pewne satyryczne przycinki wobec Sulli, jakie można znaleźć w pisemnej wersji Pro Sexto Roscio Amerino, naprawdę mogły paść z Rostry za życia dyktatora" [tamże, s. 401]. W finale powieści autor przytacza zresztą bardzo obszerne fragmenty mowy Cycerona, co wydobywa aporię wpisaną w konwencję: ciągły konflikt między prezentacją historii a budowaniem intrygi kryminalnej. Typowy czytelnik powieści detektywistycznej zapewne zechce pominąć retoryczne ekscesy starożytnego mówcy - bez wątpienia rozsadzają one fabułę.

8 Zob. M. Czubaj, Etnolog w Mieście Grzechu. Powieść kryminalna jako świadectwo antropologiczne, Gdańsk 2010, s. 37.

9 S. Saylor, Morderstwo na via Appia, w: tegoż, Historie Gordianusa, przeł. J. Szczepański, Poznań 2013, s. 447.

10 J. M. Roberts, Sprzysiężenie Katyliny, przeł. E. Wierzbicka, Warszawa 2012, s. 10.

11 Od powieści T. Wildera Idy marcowe wydanej w 1948, poprzez Kleopatrę, widowiskowy film J. Mankiewicza z 1963 r., po serial telewizyjny Rzym, wyprodukowany przez BBC i HBO w latach 2005-2007. 
cej dramaturgii zdarzeń historycznych w tych latach, co obfitości zachowanych źródeł na temat wszelkich aspektów rzymskiej rzeczywistości ${ }^{12}$. Nadto - co istotne $\mathrm{z}$ punktu widzenia poruszanych przeze mnie kwestii - $\mathrm{w}$ tym czasie zmieniło się też rzymskie postrzeganie przestrzeni. Jak pisze Mary Beard: „Jeśli, jak ujmuje to Publiusz, Rzymianie w ciągu pięćdziesięciu trzech lat, od roku 168 p.n.e. podbili niemal cały znany świat, to $w$ tym samym okresie Rzym wraz ze swoją cywilizacją również został przeobrażony [...] ${ }^{13 \prime \prime}$. Jej zdaniem ten aspekt został wyraźnie wyeksponowany w 61 r. p.n.e., w czasie triumfu Pompejusza: „uroczystość ta była najdobitniejszą jak dotąd prezentacją imperium rzymskiego $\mathrm{w}$ kategoriach terytorialnych, a nawet rzymskich ambicji podboju świata"14. I dodaje:

Ujmując to w inny sposób, Rzymianie z dnia na dzień stali się bezdyskusyjnie największymi podróżnikami świata spośród wszystkich ludów starożytnego świata śródziemnomorskiego, nie wyłączając Macedończyków Aleksandra Wielkiego czy kartagińskich kupców. Nawet przed tymi, którzy nigdy nie ruszyli się poza Rzym, otworzyły się nowe horyzonty wyobraźni, nowe widoki na odległe krainy i nowe sposoby pojmowania swego miejsca w świecie ${ }^{15}$.

Bohaterowie rzymskich kryminałów, o których tu piszę, są wyraźnie dziećmi swych czasów.

Z różnic między przywoływanymi tu cyklami wynikają też odmienności $\mathrm{w}$ prezentacji przestrzeni $\mathrm{w}$ nich przedstawionych. Zdanie Konrada Dominasa: "głównym bohaterem utworów Saylora jest Rzym"16, można właściwie odnieść do tych wszystkich serii powieściowych (choć autor ma na myśli głównie eksponowanie przez pisarza historii politycznej imperium). Ta fascynacja Rzymem przejawia się jednak również w sposobie, w jaki $\mathrm{w}$ powieściach cyklu pokazane jest miasto. $\mathrm{W}$ zestawieniu $\mathrm{z}$ serią Seylora, w SPQR widać wyraźniejsze uwypuklenie porządku czasowego - przejawia się to choćby w formułach zamykających każdy z tomów: „Powyższe wydarzenia rozegrały się podczas piętnastu dni roku 684 rzymskiego ka-

\footnotetext{
12 Zob. M. Beard, SPQR. Historia starożytnego Rzymu, przeł. N. Radomski, Poznań 2017. Pisze ona: „Nietrudno wyobrazić sobie, jak mógł wyglądać powszedni Rzym oczyma Polibiusza, gdy rozmyślał on nad pogrzebami, w których uczestniczył, lub przezornie symulował chorobę w dniu, w którym inny jeniec podjął próbę ucieczki. [...] Jednak dopiero I w. p.n.e. dostarcza nam bogatych świadectw wszystkich spraw, które obok wojny i polityki absorbowały rzymską elitę" [s. 275].

13 M. Beard, $S P Q R$, s. 183.

14 Tamże, s. 252

15 Tamże, s. 185.

16 K. Dominas, Antyk w kryminale, kryminat w antyku. Steven Saylor i recepcja literatury antycznej, w: Literatura kryminalna. Na tropie źródeł, red. A Gemra, Kraków 2015, s. 234.
} 
lendarza. Był to rok konsulatu Pompejusza i Krassusa” 17 albo „Zdarzyło się to wszystko w Galii, w roku 696 od założenia Rzymu, za konsulatu Lucjusza Pizona Cesoniusza i Aulusa Gabiniusza"18. To podkreślanie aspektu czasu widać też w konstrukcji narracji: Decjusz opowiada z perspektywy minionych lat, uwypuklając różnice między teraźniejszością a przeszłością ${ }^{19}$. Roberts używa tej konstrukcji również dlatego, że chce uniknąć kłopotliwej w przypadku powieści historycznych kwestii pogodzenia zasady prawdopodobieństwa z koniecznością wprowadzenia czytelnika w świat, który jest mu obcy, bo historycznie odległy. Stąd pojawiają się frazy: „Kimkolwiek jesteś, musisz zrozumieć, że w tamtych czasach Rzym, władający połową świata, był miejscem równie dzikim jak zapadła wioska nad Nilem" ${ }^{20}$, czy inna, przy okazji opisu spotkania bohatera z młodym Gajuszem Juliuszem Cezarem: „Widzę twój uśmiech, nawet jeśli dzielą nas setki lat. Jednak imię najczęściej trąbione w historii Rzymu nie było wówczas sławne" 21. Takie uwagi pojawiają się $\mathrm{w}$ miarę często $\mathrm{w}$ pierwszej powieści cyklu, w następnych dużo rzadziej, co zdaje się potwierdzać dodatkową funkcję - w stosunku do klasycznej powieści kryminalnej - jaką w kryminale historycznym pełni seryjność i cykliczność: pozwala zbudować świat, w którym $\mathrm{z}$ tomu na tom czytelnik będzie się poruszał swobodniej $\mathrm{w}$ realiach historycznych epoki ${ }^{22}$.

Zgodnie $\mathrm{z}$ zasadą fundującą konwencję gatunkową kryminału, we wszystkich przywoływanych tu powieściach świat konstruowany jest jako

17 J. M. Roberts, Śledztwo Decjusza, przeł. E. Wierzbicka, Warszawa 2012, s. 318.

18 J. M. Roberts, Detektyw Cezara, M. Kompanowski, Warszawa 2014, s. 317.

19 Aczkolwiek w opowieści Decjusza brak mitologizującej czy demonizującej przesłony, częstej we wspomnieniach o przeszłości. Pisze: „Tak, to były złe czasy, ale w swoim długim życiu wielokrotnie dochodziłem do wniosku, że wszystkie czasy są złe, a stare dni idealnej szlachetności i cnoty tak naprawdę nigdy nie nadeszły - są jedynie wytworem fantazji poetów i moralistów" [J. M. Roberts, Śledztwo Decjusza, przeł. E. Wierzbicka, Warszawa 2012, s. 55].

20 J. M. Roberts, Śledztwo Decjusza, s. 13.

21 Tamże, s. 20. Lindsey Davis rozwiązuje kwestię godzenia prawdopodobieństwa i potrzeby dostarczenia czytelnikowi wiedzy niezbędnej do poruszania się po przedstawianym świecie nieco podobnie. Falko - bohater i narrator, informuje na przykład: "Jeśli istnieje jakaś kategoria osobników, których nienawidzę bardziej od innych, to są nimi edyle. Gwoli informacji dla obywateli prowincji ..." [L. Davis, Srebrne świnki, s. 67]. Tutaj zakładana niewiedza odbiorcy ma wynikać z oddalenia w przestrzeni, u Robertsa - w czasie.

22 Zob. A. Izdebska, hasło: kryminał historyczny, s. 140. Zob. też M. Kraska, Prosta sztuka zabijania. Figury czytania kryminału, Gdańsk 2013. Kraska twierdzi, że fabuła powieści kryminalnej, pozornie skonstruowana jako zamknięta, „w istocie rzeczy okazuje się tylko maskować to, że z punktu widzenia odbiorcy - nie ma prawa się skończyć. Holmes, tak jak Poirot, po każdym skończonym śledztwie musi przecież podjąć następne, a dzieje się tak nawet wtedy, gdy Conan Doyle swojego detektywa zapragnął uśmiercić" [s. 139]. 
realistyczny, w tym wypadku odsyłający czytelników do rzeczywistości czasowo (i zapewne mentalnie) odległej od codzienności odbiorcy. Owo osadzenie $\mathrm{w}$ konkretnych realiach historycznych podkreślane jest - we wszystkich tekstach - zamieszczaniem map miejsc, w których rozgrywa się akcja. Przestrzeń przedstawiona współtworzy zatem - co oczywiste - ów świat skonstruowany jako wiarygodny, bo udokumentowany źródłowo.

Zdarzenia w powieściach składających się na przywołane tu trzy cykle rozgrywają się w różnych miejscach Imperium: na jego obrzeżach, w Brytanii i Germanii, poza jego granicami, w Petrze, Damaszku, Pamirze, ale przede wszystkim w samym Rzymie: to jego przestrzeń jest punktem centralnym opowieści. We wszystkich powieściach Rzym - abstrahując od osadzenia tego obrazu w realiach historycznych - jest przede wszystkim tyglem, w którym miesza się ludzki żywioł, miastem miast, centrum świata. Jego obraz ukształtowany został wedle współczesnych wyobrażeń o funkcjonowaniu metropolii. Główni bohaterowie Saylora, Robertsa i Davis kochają Rzym, znają jego rozmaite wcielenia, a $\mathrm{w}$ przestrzeni miasta poruszają się swobodnie: to ich miejsce $w$ świecie.

Gordianus poświęca opisowi stolicy imperium niejeden fragment - najbardziej rozbudowany znajduje się na początku Rzymskiej krwi:

Żadne ze znanych mi miast nie może dorównać Rzymowi tą czystą witalnością porannego szczytu. Rzym budzi się po nocy z pełnym samozadowolenia przeciąganiem się i głębokim wdechem, pobudzającym płuca i przyspieszającym puls. Rzym budzi się z uśmiechem wywołanym przyjemnymi marzeniami, ponieważ co wieczór zasypia śniąc sen o imperium. Rano otwiera oczy, gotów zająć się realizacją tego snu w jasnym świetle dnia ${ }^{23}$.

Ta personifikacja ${ }^{24}$ bez wątpienia ma podkreślać witalność wpisaną w porządek miasta. Miasta w stanie ekspansji, żyjącego bardziej przyszłością niż historią, prącego ku nowym wyzwaniom. Gordianus jest wyznawcą Rzymu: „To miasto jest jak wiele miast w jednym. O każdej godzinie można zobaczyć co najmniej kilka jego wcieleń" 25 . Dla Poszukiwacza ta wielość, kontrasty,

\footnotetext{
23 S. Saylor, Rzymska krew, s. 29.

24 Personifikacje Rzymu relatywnie często pojawiają się w powieściach Saylora. Na przykład Gordianus w czasie rozmowy z Witruwiuszem, zapewniając go, że w Rzymie pod rządami Marka Antoniusza, w jednym z najgorętszych okresów schyłku republiki, nikt raczej nie myśli o zabawach, tak podsumowuje w myślach nastroje mieszkańców: „Miasto, oszołomione chaosem ostatnich miesięcy i niepewne jutra, wstrzymało oddech i chodziło na palcach z okrągłymi oczami jak dziewica w puszczy" [S. Saylor, Ostatnio widziany w Massili, w: tegoż, Tajemnice Gordianusa, s. 308].

25 Tamże, s. 29.
} 
które niesie, są jednym z powodów zachwytu Rzymem. To centrum świata, budzące w nim nieodmiennie zachwyt:

Co za niesamowite miasto! - powiedziałem głośno. [...] Rzym jest środkiem świata ze wszystkimi jego wadami i zaletami. Mimo trapiących i świat i mnie problemów [...] taki widok w piękny poranek wciąż jeszcze mógł napełnić mnie młodzieńczą nadzieją i poczuciem, że wszystko jest jeszcze możliwe ${ }^{26}$.

Rzym to model świata dający się ogarnąć wzrokiem, jakoś topograficznie okiełznać, a zatem i poznać, źródło energii dla jego mieszkańców.

W SPQR Rzym pokazywany jest w większej mierze jako nakładające się na siebie porządki topograficzno-czasowe. Decjusz pisze na przykład z rozrzewnieniem:

W Rzymie, przy całym jego ogromie i różnorodności, najbardziej pokochałem Forum. [...] W czasach, które tu opisuję, Forum było fantastycznie bezładną mieszaniną świątyń, po części jeszcze drewnianych, straganów targowych, budek wróżbiarzy, trybun do wygłaszania przemówień, pomników dawnych wojen, gołębników na ptactwo ofiarne; dla mieszkańców centrum świata stało się miejscem oczekiwania, leniuchowania i plotkowania. Teraz oczywiście jest marmurowym dziełem, wzniesionym ku czci jednej rodziny i nie odgrywa już roli antycznego miejsca zebrań klanowych ani rynku, który tak kochałem. Z radością jednak stwierdzam, że gołębie "ozdabiają" nowe pomniki równie ochoczo, jak dawniej stare ${ }^{27}$.

Forum pełni tu też - jak i w powieściach Saylora zresztą - funkcję wyrazistego sygnału historyczno-przestrzennego: Forum Romanum synekdochicznie przywołuje tu całe miasto i imperium.

Forum Robertsa nie jest podobne do tego, które znamy z opowieści Gordianusa. Organizacja przestrzeni przedstawionej w cyklu Saylora jest w dużej mierze pochodną wyraźnie eksponowanych źródeł, z których czerpie inspirację autor: mów Marka Tuliusza Cycerona i jego korespondencji. Zatem w „Roma sub rosa” ważna jest przede wszystkim Rostra ${ }^{28}$ - mównica, z której Cycero wygłasza w Rzymskiej krwi mowę obrończą w procesie Sekstusa Roscjusza i która powraca jako punkt centralny w wielu kolejnych powieściach Saylora. Gordianus nie jest w stanie oprzeć się „zewowi Forum”, bo jak

\footnotetext{
26 S. Saylor, Mgliste proroctwa, w: tegoż, Tajemnice Gordianusa, s. 625-626.

27 J. M. Roberts, Śledztwo Decjusza, s. 18-19.

28 J. M. Roberts, Sprzysiężenie Katyliny, „Słownik pojęć” z zastrzeżeniem, że „definicje odnoszą się do ostatniego stulecia republiki”. „Rostra: postawiony na terenie Forum Romanum pomnik upamiętniający bitwę morską pod Antium stoczoną w 338 roku p.n.e. Pomnik udekorowano dziobami (rostrum - dziób, l.mn. rostra) okrętów zdobytych przez Rzymian. Podstawa pomnika pełniła funkcje mównicy" [s. 338].
} 
twierdzi: „W czasie kryzysu i podczas świąt coś w Rzymianinie ciągnie go nieodparcie, by dołączyć do współobywateli i słuchać mów wygłaszanych pod gołym niebem, gdzie mogą je słyszeć i ludzie i bogowie" 29 .

Jeśli Forum pokazywane jest jako wyrazisty znak miasta, warto przywołać sceny ze Sprzysiężenia Katyliny Robertsa, w których autor wyraźnie przyjmuje strategię eksponowania przeszłości historycznej jako przede wszystkim doświadczeniowo obcej współczesności. Otóż Decjusz, bohater powieści, decyzją sąsiadów ma reprezentować Suburę ${ }^{30} \mathrm{w}$ dorocznym October Equus, Święcie Październikowego Konia, uroczystości zamykającej agrarny i militarny rok w Rzymie ${ }^{31}$. Tym razem tradycyjny wyścig ma się odbyć w murach miasta, nie na Polu Marsowym, gdyż ",augurowie dostrzegli znaki niesprzyjające uczczeniu tej uroczystości w tym miejscu" ${ }^{32}$. Ta zamiana oznacza, że uczestnicy będą się ścigać konno, nie na rydwanach, co stwarza bohaterowi szansę wygranej: Decjusz uważa się za „kompetentnego jeźdźca, lecz żałosnego woźnicę". W rezultacie czytelnik otrzymuje opis gonitwy na nieosiodłanych koniach na Forum, po wąskim, wyznaczonym linami torze, wyścigu, w trakcie którego zawodnicy i ich przyboczni mają prawo wszelkimi środkami unieszkodliwić przeciwnika i zrzucić go z siodła. Ponieważ to uroczystość na cześć Marsa, wyścig koni, nie jeźdźców, zwycięski siwek, na którym Decjusz dociera do mety, zostaje złożony w ofierze. Koń otrzymuje cios $\mathrm{w}$ głowę, a kapłan podrzyna mu gardło. Dalsza, kulminacyjna część uroczystości to wyścig z uciętą głową konia po wąskich uliczkach, bieg, w którym każdy z uczestników usiłuje dobiec z nią do centralnego punktu własnej dzielnicy. $Z$ dachów dosięgają biegnących rozmaite przedmioty - z nożami włącznie: mieszkańcy dzielnie wspomagają swych reprezentantów. I tym razem zwycięża mocno poturbowany Decjusz, a skrwawiona głowa końska zostaje umieszczona triumfalnie w Sali Cechu: „Subura odzyskała swoje szczęście, a radość z tego powodu była ogłuszająca. Przynajmniej tak mi później mówiono. Straciłem przytomność w czasie obmywania końskiego łba" ${ }^{33}$. To obraz Rzymu odbiegający od potocznych, skonstruowa-

29 S. Saylor, Morderstwo na via Appia, w: tegoż, Historie Gordianusa, s. 468.

30 Bohater Robertsa nie może odmówić tego niebezpiecznego zaszczytu - konkurentów z Via Sacra w wyścigu reprezentuje Publiusz Klodiusz, jego wróg: „Byłem w potrzasku. Jeśli wycofam się ze spotkania z Klodiuszem, mogę od razu na dobre wyjechać z miasta i udać się na Rodos lub w inne podobne miejsce i zająć studiowaniem filozofii" [J. M. Roberts, Sprzysiężenie Katyliny, s. 166]. Wątek Subury, jako bardzo malowniczej dzielnicy Rzymu, pojawi się jeszcze $\mathrm{w}$ moim tekście.

31 Zob. C. Bennet Pascal, October Horse, „Harvard Studies in Classical Philology” 1981 (85).

32 J. M. Roberts, Sprzysiężenie Katyliny, s. 185.

33 Tamże, s. 204. 
nych w obrębie kultury popularnej wyobrażeń o przestrzeni Wiecznego Miasta u schyłku republiki ${ }^{34}$.

Rzym prezentowany we wszystkich opisywanych tu cyklach kryminałów to miasto permanentnie się zmieniające, tworzące chaotyczną zbieraninę budynków, stylistycznie, subtelnie rzecz ujmując, eklektyczną:

Wokół Circus Flaminius roztacza się labirynt wąskich uliczek. [...] Wszystkie [...] są do siebie bliźniaczo podobne i przedstawiają mieszaninę wszystkich architektonicznych wzorów i epok. Z powodu częstych trzęsień ziemi i pożarów Rzym jest bezustannie odbudowywany i przebudowywany. $\mathrm{W}$ miarę przyrostu ludności i skupienia własności gruntu w rękach wielkich posiadaczy, nowe domy często buduje się wedle najgorszych wyobrażalnych planów i przez najgorszych rzemieślników. Wokół szacownych murowanych budynków, które jakoś przetrwały stulecia katastrof, można ujrzeć byle jakie konstrukcje [...] wyglądające jak ulepione z błota i patyków ${ }^{35}$.

To miasto uosabia witalny chaos, a rzymska recepta na bezustanną przemianę jest dość radykalna: „Rzym jest miastem dymu i ognia” 36 , mówi bohater Saylora, a Decjusz zdaje się mu wtórować: „choć podpalenia wzbudzały ogromny strach, zdarzały się w Rzymie niewiele rzadziej od przypadków zwykłego kataru" ${ }^{37}$. W rezultacie tego radosnego autodestrukcyjno-konstrukcyjnego procesu w Rzymie trudno gdziekolwiek trafić. Gdy bohater Robertsa chce odwiedzić potencjalnego klienta, otrzymuje tak skomplikowaną instrukcję, że każe się tam po prostu zaprowadzić i komentuje: "Jeśli chcesz kogoś do siebie zaprosić, posyłasz po niego niewolnika. Jeśli nie stać cię na niewolnika, jest i tak mało prawdopodobne, by ktoś chciał cię odwiedzić" 38 .

To eklektyczne i chaotyczne centrum imperium zasypia późno, jakby wieczny ruch nadawał mu impet konieczny do funkcjonowania:

Z nastaniem mroku inne miasta cichną, ale w Rzymie wczesne godziny wieczorne to najgłośniejsza pora. Zapewne dlatego, że - poza paroma wyjątkami ruch kołowy jest $\mathrm{w}$ ciągu dnia zakazany. $\mathrm{Z}$ nastaniem nocy przez bramy wjeżdżają niezliczone ilości wozów i furmanek. [...] O tej porze ulice Rzymu są głośne od szczęku metalowych obręczy uderzających o bruk, nieopisanego pisku prymitywnych, drewnianych kół, umocowanych na osiach wiejskich furmanek, przekleństw woźniców, jęków powiązanych niewolników, ryku wołów i osłów. Dopiero po północy nastaje cisza ${ }^{39}$.

\footnotetext{
34 Serial Rzym i triumf Cezara z twarzą wymazaną ochrą.

35 J. M. Saylor, Rzymska krew, s. 97-98.

36 Tamże, s. 140 (I, 140).

37 J. M. Roberts, Śledztwo Decjusza, s. 58.

38 J. M. Roberts, Sprzysiężenie Katyliny, s. 98.

39 J. M. Roberts, Śledztwo Decjusza, s. 145.
} 
Sposób pokazywania miasta jest też w pewnej mierze pochodną statusu społecznego bohaterów rzymskich kryminałów. Najniżej w hierarchii tkwi Falko, skazany na mieszkanie w „złej” dzielnicy i kiepskim domu:

Spośród wszystkich nędznych kamienic czynszowych, we wszystkich obskurnych zaułkach tego miasta, domy przy Dziedzińcu Fontanny na pewno są najpodlejsze. Tuż obok jednej z najważniejszych arterii cesarstwa, wspaniałej drogi Ostyjskiej, ten wrzód pod pachą Awentynu to zupełnie inny świat. [...] Było tu tanio (jak na Rzym), ale czasami wydawało mi się, że lepiej byłoby zamieszkać pod gołym niebem w jakieś lepszej dzielnicy. Mieszkałem na najwyższym piętrze wielkiej, rozpadającej się czynszówki. Cały parter zajmowała pralnie: wełniane tuniki czekające na odebranie były jedynymi czystymi rzeczami w tej okolicy ${ }^{40}$.

W kryminałach Saylora i Robertsa dzielnicą skupiającą jak w soczewce całą żywotność, kontrastowość miasta i jego niebezpieczeństwa jest Subura. To jakby mniejszy tygiel w gigantycznym tyglu, w którym powstaje niepowtarzalna mieszanka fascynująca i zarazem odstręczająca opowiadających o niej bohaterów ${ }^{41}$. Lucjusz Klaudiusz, arystokrata zaprzyjaźniony z Gordinusem, mówi do niego:

A zatem rozumiesz także, dlaczego uwielbiam Suburę. Cóż to za dzielnica! Aż pulsuje, niemal pachnie namiętnością. Zatłoczone kamienice, dziwne wonie, cały ludzki teatr! Kręte i wąskie uliczki, mroczne alejki, płynące z pięter odgłosy kłótni, śmiechu, miłości... To tajemnicze miejsce pełne życia! - W nędzy nie ma nic tajemniczego - zauważyłem. - Ależ jest! - upierał się Lucjusz ${ }^{42}$.

Dla bogatego patrycjusza Subura to fascynująco prawdziwe teatralne dekoracje - Gordianus zaś jest świadom autentyczności tego miejsca i codzienności jego mieszkańców. Dlatego jest ono dla niego punktem odniesienia, przykładem wszystkiego, co w Rzymie najgorsze. Gdy miasto za jego życia się zmienia ze względu na polityczny chaos, natychmiast to zauważa:

Palatyn wydawał mi się dziś szczególnie uroczy. Ostatnio za każdym razem, kiedy wychodziłem poza najbliższe okolice własnego domu, byłem zszokowany brudem i niechlujnością, jakie opanowały większą część Rzymu, zwłaszcza Su-

\footnotetext{
40 L. Davis, Miedziana Wenus, przeł. K. Majchrzak, Poznań 2009, s. 31.

41 W Sprzysiężeniu Katyliny, w dołączonym do powieści słowniku pojęć, Roberts tak charakteryzuje tę dzielnicę: „położona w niższej części Wiminalu i Eskwilinu, słynąca z nędznych domów, hałaśliwych mieszkańców i krzykliwych sprzedawców" [J. M. Roberts, Sprzysiężenie Katyliny, s. 340], domów publicznych i tawern, dodajmy.

42 S. Saylor, Dom westalek, w: tegoż, Zagadki Gordianusa, s. 462.
} 
burę z jej tawernami, burdelami i cuchnącymi bocznymi uliczkami, a nawet Forum wypełnione hordami odzianych w togi polityków i bankierów, uwijających się jak w gorączce wokół swoich spraw. O ileż przyjemniej jest na Palatynie: cieniste, dobrze wybrukowane aleje, staroświeckie sklepiki, zadbane kamienice i ładne wille. [...] Po prostu przywykłem do mieszkania w zamożnej dzielnicy, co nie przyszło mi z najmniejszym trudem ${ }^{43}$.

Zmiana statusu majątkowego Gordianusa, awans w hierarchii społecznej, owocuje - co nie dziwi - ewolucją jego stosunku emocjonalnego do rozmaitych dzielnic miasta. I choć jego admiracja dla Rzymu jest niezmienna, najwyraźniej woli się nim zachwycać z perspektywy spokojnego Palatynu, nie zaś Subury, której malowniczość w takiej optyce nie wydaje się specjalnie pociągająca.

W Wespazjańskim Rzymie Falkona rolę „złej dzielnicy” pełni Zatybrze, wyraźnie wystylizowane na miejsce zamieszkane przez kolorowych imigrantów:

W dzień wypluwa swoich mieszkańców na drugą stronę rzeki, gdzie handlują swoimi niestrawnymi plackami, wilgotnymi knotami, tandetnymi zielonymi naszyjnikami, amuletami, zaklęciami, możliwością korzystania przez chwilę z siostry handlarza w krypcie świątyni Izydy, za pół asa numerek (i nie zdziw się, jeśli złapiesz coś nieuleczalnego). [...] Nocą wszyscy oni wracają, niczym mroczny ściek wsączając się w labirynt czternastej dzielnicy. [...] W ciepłym powietrzu, przesyconym orientalną wonią, słychać dźwięki brzękliwej, obcej muzyki dochodzące zza okratowanych drzwi ${ }^{44}$.

Takie dzielnice należy omijać, ale oczywiście to tam detektyw - jak Chandlerowski Philip Marlow - musi się zapuścić, by dociekać prawdy.

W Rzymie opisywanych tu powieści kryminalnych, jak w każdym mieście w historii cywilizacji, istnieje stratyfikacja społeczna, która ma swoje odzwierciedlenie w dostępie do przestrzeni miasta. Gdy Gordianus odwiedza patrycjuszowską willę, zostaje zaproszony do miejskiego ogrodu właścicieli:

Posiadanie skrawka zieleni nad brzegami Tybru jest oznaką zamożności i dobrego smaku. Takie posiadłości są najczęściej czymś pośrednim między ogrodem i parkiem. Właściciele nazywają je horti. [...] Ogród Klodii znajdował się nadspodziewanie blisko. Sto lat temu ta godna pozazdroszczenia nadrzeczna posiadłość musiała leżeć daleko za murami, ale przez ten czas miasto się znacznie rozrosło i wchłonęło ją. Musiała od pokoleń należeć do jej rodziny ${ }^{45}$.

\footnotetext{
43 S. Saylor, Rzut Wenus, w: tegoż, Historie Gordianusa, s. 136.

44 L. Davis, Wykute w brązie, s. 528.

45 S. Saylor, Rzut Wenus, s. 98-99.
} 
Posiadacze "starych" pieniędzy posiadają też fragmenty przestrzeni, które wobec ekspansji miasta zyskują niejako status eksterytorialności: Rzym je pochłania, zmienia się wokół nich w swojej gorączkowej przemianie, a one trwają jako relatywnie niezmienne.

W opowieściach o rzymskich detektywach pojawiają się też opisy przestrzeni domowej - od obskurnych pokoików Falkona po willę Lukullusa i wiejskie posiadłości wśród oliwnych gajów. Wnętrza domów charakteryzujące ich mieszkańców występują najczęściej u Saylora. Ponieważ Cycero (ze względu na wykorzystanie jego korespondencji oraz mów jako historycznego źródła i fabularne konsekwencje tego zabiegu) jest jedną z głównych postaci $\mathrm{w}$ wielu powieściach cyklu, jego dom kilkakrotnie jest miejscem powieściowych zdarzeń. Gordianus przy pierwszym spotkaniu z mówcą, zaproszony do jego willi, czerpie wiedzę o gospodarzu ze szczegółowo opisanej przestrzeni domu i miejsca spotkania:

był to zatem gabinet i biblioteka Cycerona. Takie pokoje są często bardzo osobiste, więcej mówią o swych właścicielach, niż sypialnie czy jadalnie, będące domeną kobiet i niewolników [...] Cóż za człowiek przyjmuje gości w bibliotece, zamiast $\mathrm{w}$ jadalni czy na tarasie? Człowiek o greckich upodobaniach, pomyślałem. [...] Ktoś, kto otwiera konwersację z zupełnie obcymi ludźmi takim gambitem: - Powiedz mi, Gordianusie Poszukiwaczu, czy kiedykolwiek rozważałeś zabicie ojca? ${ }^{46}$

W innym miejscu Gordianus jest pod wrażeniem znakomitego smaku słynnego prawnika:

Udaliśmy się do niewielkiego, dobrze ogrzanego pokoju na tyłach domu. Po drodze miałem okazję rozejrzeć się po wnętrzu. Meble, draperie, obrazy i mozaiki były w najlepszym gatunku. [...] Cycero zawsze wykazywał nienaganny smak. Zawsze też miał wystarczająco dużo pieniędzy, by się nim kierować [...] Trzeba dysponować prawdziwą fortuną, aby pozwolić sobie na przykład na fontannę wykładaną złoconą mozaiką, na obraz z podpisem Iai z Kyziko albo na wystawiony na osobnym stole pod szklaną taflą fragment oryginalnego pergaminu z dialogiem Platona z jego własnoręcznie naniesionymi poprawkami ${ }^{47}$.

To wnętrze stanowi kontrast z willą Werresa, wygnanego z Rzymu i mieszkającego w greckiej kolonii, Massilii. Przepych jego domu wydaje się Gordianusowi ostentacyjny i - do pewnego stopnia - nie-rzymski:

\footnotetext{
46 S. Saylor, Rzymska krew, s. 44-45. Nawiasem, w cytacie widać pułapki konwencji: szachy bez wątpienia nie były grą znaną w starożytnym Rzymie, zatem słowo gambit nie ma prawa pojawić się w umyśle Gordianusa, zaś opis rzymskiego domu bez wątpienia nie jest przeznaczony dla współczesnych detektywa.

47 S. Saylor, Morderstwo na Via Appia, s. 456.
} 
Obrazy i rzeźby były dosłownie wszędzie. [...] Nie mogłem dopatrzyć się żadnej celowości w ich ustawieniu: Diana z napiętym łukiem wbijała łokieć w nos jakiegoś anonimowego sycylijskiego notabla, mierząc grotem wprost w głowę stojącego o parę stóp Jowisza, którego surowe spojrzenie skierowane było na dwa naturalnej wielkości marmurowe jelenie wspinające się na tylne nogi. [...] Krocząc tak przez korytarze i kolejne pokoje, nie mogłem oprzeć się wrażeniu, że trafiłem na wielkie, tłoczne, ale złowrogo milczące przyjęcie, na które sproszono przedziwną mieszaninę gości z marmuru i brązu: bogów i zwierzęta, umierających Galów i baraszkujących satyrów, nagich efebów i dawno zmarłych poetów. Takie traktowanie dzieł sztuki, a zwłaszcza podobizn bogów [...] było niemal świętokradztwem. Zadrżałem ${ }^{48}$.

Estetyczny ład Cyceronowskiej willi koi zmysły Gordianusa, barbarzyński chaos domu Werresa - przeraża. Kwalifikacje moralne obu właścicieli zdają się zatem mieć odzwierciedlenie w porządku wnętrz ich siedzib.

Zdarzenia $w$ powieściach tworzących przywołane tu trzy cykle rozgrywają się w różnych miejscach Imperium, często na jego obrzeżach, w Brytanii i Germanii, czy poza jego granicami, na przykład w Petrze czy Palmirze. Zatem bohaterowie Rzym opuszczają, udając się czasami w jego najbliższe otoczenie. Gordianus na przykład rozwiązuje zagadkę związaną z okolicznościami zabójstwa Publiusza Klodiusza, populistycznego przywódcy zdolnego pociągnąć za sobą rzymską ulicę, którego śmierć wywołuje zamieszki. Został on zamordowany na Via Appia i Gordianus wyprawia się za miasto, by zbadać okoliczności zabójstwa. Opowieść o tym śledztwie jest też historią drogi, miejsca granicznego, w którym miasto traci swój kształt i odrębność:

Za linią grobowców widniały stosy śmieci i gruzu, skorup potłuczonych garnków i zdartych butów, skrawków metalu i kawałków tynku. Miasto tak duże jak Rzym wytwarza wielką ilość śmieci i muszą się gdzieś podziać. Lepiej wywieźć je taczkami za mury i wyrzucić w mieście umarłych, niż miałyby się walać pod nogami żyjących. Tam, gdzie ostatecznie kończą się wpływy miasta, gdzie grobowce i sterty śmieci stają się coraz mniejsze i rzadsze, a krajobraz na dobre zmienia się $\mathrm{w}$ wiejski, przejeżdża się obok pomnika Basiliusa ${ }^{49}$.

To, co z miasta usunięte, wyznacza teren "pomiędzy” - Rzym naznacza sobą swoje peryferia. Gordianus zachwyca się doskonałością drogi:

Kamienie tak perfekcyjnie przycięte i dopasowane, nawierzchnia tak gładka i równa, a przy tym jaka szeroka: dwa wozy mogą się minąć, nawet na chwilę nie przystając. Można by pomyśleć, że sami bogowie ją stworzyli, ale nie, to Appiusz Klaudiusz Cerkus, pradziad naszego Publiusza Klaudiusza ${ }^{50}$.

\footnotetext{
48 S. Saylor, Ostatnio widziany w Massili, s. 390-391.

49 S. Saylor, Morderstwo na Via Appia, s. 559.

50 Tamże, s. 568.
} 
Gordianus ostatecznie dociera do prawdy o okolicznościach śmierci Publiusza Klodiusza. Od rzeczywistej zabójczyni, której tożsamości obiecuje nie ujawniać, otrzymuje pierścień należący do zmarłego:

Podniosłem go do światła i zauważyłem zdobiący obie strony, wewnętrzną i zewnętrzną, delikatny deseń złożony z przylegających do siebie bokami sześciokątów, jak dokładnie dopasowane kamienie brukowe Via Appia. Pierścień był odwzorowaniem słynnego traktu, hołdem dla miejsca, gdzie człowiek, który go nosił, padł pod ciosami wrogów i oddał ostatnie tchnienie z błękitną wstążką zaciśniętą wokół szyi ${ }^{51}$.

Los potomka twórców najsłynniejszej z dróg wiodących do Rzymu splótł się $\mathrm{z}$ tym miejscem nierozerwalnie, jak gdyby miało ono tajemną władzę nad wszystkimi Klaudiuszami.

Jednym z problemów, z którymi musi zmierzyć się twórca kryminału historycznego, jest konieczność wiarygodnego splecenia intrygi kryminalnej $\mathrm{z}$ „wielką historią". Próby pogodzenia tych dwóch porządków podejmują właściwie wszyscy autorzy piszący w tej konwencji - atrakcyjność fabuły jest tu przecież wymogiem gatunkowym niejako. W cyklu Saylora Gordianus Poszukiwacz (podobnie jak bohater Robertsa) jest blisko spisku Katyliny, który może wstrząsnąć Rzymem, zapobiega zamachowi na Cezara, a w czasie wyprawy do Aleksandrii jest nie tylko świadkiem zabójstwa Pompejusza, ale i obserwuje brawurowe zjawienie się Kleopatry w komnacie Gajusza Juliusza. Saylor konstruuje swojego bohatera jako świadka nieomal wszystkich najważniejszych wydarzeń historycznych w okresie od końca dyktatury Sulli po schyłek życia Cezara.

Nieco podobnie rzecz się ma z bohaterem Davis. Falko odkrywa kulisy spisku zmierzającego do zgładzenia Wespazjana, a gdy udaje się do Germanii, trafia oczywiście do Lasu Teutoburskiego, jedynego zapewne miejsca w tym odległym kawałku świata znanego wszystkim Rzymianom. Ten las zyskał złą sławę ze względu na spektakularną rzeź legionów Warrusa, klęskę, która zahamowała ekspansję imperium na zachodzie Europy:

Nie szukaliśmy kopca. [...] Czciliśmy ich pamięć w milczeniu. [...] Myśląc o przeszłości, zastanawialiśmy się, czy ktokolwiek miałby szanse dowiedzieć się o naszym losie, gdybyśmy to teraz my polegli w tym lesie. [...] Podobnie jak armia Warrusa kierowaliśmy się na południe. Podobnie jak tamci ludzie dążyliśmy ku swemu przeznaczeniu. Różnica była taka, że my wiedzieliśmy ${ }^{52}$.

\footnotetext{
51 S. Saylor, Morderstwo na Via Appia, s. 813.
}

52 L. Davis, Żelazna ręka Marsa, s. 350-351. 
W dziczy Falko i jego towarzysze trafiają zatem na miejsce naznaczone upiorną obecnością Rzymu, poruszają się śladami współobywateli miasta, rozważając okoliczności zagłady legionów. Zgadzają się ze zdaniem jednego ze swych kompanów, że pole bitwy jest wszędzie wokół nich, bo nie da się wybić „dwudziestu tysięcy żołnierzy ... weteranów wielu kampanii... na terenie wielkości podwórka" ${ }^{53}$. Mimo ogromnej odległości dzielącej ich od Forum, znajdują się w miejscu, w którym decydowała się kiedyś przyszłość imperium, punkcie na nieistniejącej mapie, w którym uformował się kształt świata, w którym żyją i z którego posłano ich raz jeszcze do tego przeklętego lasu.

Marek Dydiusz Falko jest też najbardziej zagorzałym podróżnikiem spośród rzymskich detektywów, stąd też w powieściach Davis znajdziemy opisy wielu różnych miejsc w świecie epoki Wespazjana. Autorka pozwala sobie nawet na metatekstowy żart i w Ostatnim akcie w Palmirze czytamy: „Kapitolias miało wszelkie cechy miasta należącego do Dekapolis. Nie jestem autorem przewodników turystycznych... sami możecie sobie uzupełnić szczegóły" 54 .

Falko nie jest specjalnym entuzjastą pograniczy imperium: „Jeśli kiedyś przyjdzie wam do głowy, by się wybrać do Brytanii, zdecydowanie odradzam. Jeśli nie uda wam się tego uniknąć, odkryjecie, że ta prowincja znajduje się poza zasięgiem cywilizacji, w królestwie Wiatru Północnego" ${ }^{55}$. Jednak Londinium budzi jego podziw:

Kiedy ostatni raz widziałem Londinium, było cuchnącym wielkim polem popiołów, po którym turlały się czaszki zmasakrowanych osadników [...] Teraz to nowy ośrodek administracji. [...] Napotkaliśmy w doskonałym stanie most, schludne nabrzeża, tawerny i łaźnie; wszystko to miało nie więcej niż dziesięć lat. Czułem zapachy zarówno znajome, jak i egzotyczne. Ledwie się rozejrzawszy, usłyszałem sześć języków ${ }^{56}$.

Gdy Falko znajduje się na granicy imperium, część opisów tych terenów spełnia typową dla powieści historycznej funkcję poznawczą - dostarcza czytelnikowi wiedzy o świecie mu obcym, bo czasowo odległym:

\footnotetext{
53 Tamże, s. 351.

54 L. Davis, Ostatni akt w Palmirze, s. 347. W Miedzianej Wenus zaś czytamy: „Gotów byłem przyznać, że pewnego dnia trzy zimne prowincje galijskie wniosą swój wkład w sztukę cywilizowanego świata... ale nikt mnie nie przekona, że będzie to wyższa sztuka kulinarna" [L. Davis, Miedziana Wenus, s. 223].

55 L. Davis, Srebrne świnki, s. 135.

56 Tamże, s. 142-143.
} 
Już samo pogranicze było dość niepewne. Europę zamieszkiwały niespokojne plemiona [...] Od czasów Juliusza Cezara Rzym starał się osiedlać przyjazne ich grupy w taki sposób, żeby powstawały strefy buforowe. Nasze prowincje Germanii Górnej i Dolnej tworzyły wojskowy korytarz wzdłuż Renu pomiędzy spacyfikowanymi krainami w Galii i wielkim nieznanym. [...] Starannie przestudiowałem mapę. Na dalekiej prowincji, wokół ujścia Renu, leżała ojczyzna Batawów, z fortecą, która nazywali po prostu Wyspą. Wzdłuż rzeki stały rzymskie warownie, posterunki, wieże strażnicze, które wybudowano, by kontrolować Germanię $[\ldots]^{57}$.

Jednak granica Imperium to coś więcej niż element geograficzno-przestrzenny: Helena, ukochana Falkona, uświadamia mu to: „Popatrz, Marku. To prawie inny kontynent. Antyteza wszystkiego, co rzymskie. Ludy wędrowne. Bezimienne bóstwa w głuszy. Żadnych dróg. Fortec. Miast. Nie ma Forum, nie ma łaźni publicznych, sądów. Nie istnieje żadne zorganizowane życie i nie ma władzy, do której można by się odwołać" ${ }^{58}$. Antyteza rzymskości zawiera w sobie oczywiście obraz tego, czym jest Rzym dla bohaterów Davis: między innymi porządkiem, w który przestrzeń została ujęta i przekształcona. Kwintesencją owego ładu - nie bez historycznego uzasadnienia, oczywiście - są drogi, miasta, łaźnie i instytucje państwa. To, co rozciąga się poza granicami Imperium, jest zatem z gruntu obce, a nawet nierzeczywiste. W czasie podróży na wschód Falko tak postrzega Damaszek, gdy dociera tam $\mathrm{z}$ trupą teatralną:

Ze wszystkich miast, jakie widzieliśmy, to najbardziej przypominało scenografię tętniącej życiem greckiej sztuki, wyglądało na takie miejsce, gdzie porzuca się niemowlęta, dochodzi do kradzieży skarbów, zbiegli niewolnicy czają się za każdą kolumną, a prostytutki rzadko dożywają wieku emerytalnego. Tutaj, niewątpliwie wytworne małżonki beształy swoich wątłych mężów za to, że nie sprawdzają się w łożu. Marnotrawni synowie przechytrzali swych zramolałych ojców ${ }^{59}$.

Obcość poza granicami imperium wydaje się stopniowalna. Szczególnie mocno odczuwa to Falko na wschodzie właśnie:

Bywałem już wcześniej na krańcach imperium. Nawet przekraczałem granice [...] A przecież kiedy wędrowaliśmy na wschód, w głąb Syrii, miałem uczucie, jakiego nie doznawałem nigdy wcześniej, że w pobliżu są jacyś zupełnie nieznani barbarzyńcy. W Brytanii czy Germanii wiadomo, co człowieka

\footnotetext{
57 L. Davis, Żelazna ręka Marsa, s. 89.

58 Tamże, s. 303.

59 Tamże, s. 405.
} 
czeka po drugiej stronie granicy: jeszcze więcej Brytów czy Germanów, z natury zbyt bitnych, by dać się podbić, a ich ziemie są zbyt niefortunnie położone, by dało się je zająć. Za Syrią [...] żyją niepokonani Partowie. A dalej ciągną się legendarne, nieodkryte terytoria, tajemnicze królestwa, skąd pochodzą egzotyczne towary, sprowadzane przez skrytych ludzi i przewożone na grzbietach dziwacznych zwierząt ${ }^{60}$.

Wobec napierającej odmienności, nie-rzymskości wschodu, znużony podróżą Falko doznaje spazmu tęsknoty za tym, co swojskie:

Dość tego. Niedobrze mi się robiło od kamyków w bucie i nieprzyjemnie ostrego zapachu wielbłądzich oddechów Tęskniłem za wspaniałym pomnikami i wysokimi kamienicami z mrowiem lokatorów. Chciałem, by sprzedano mi wątpliwej świeżości rybę, smakującą mułem z Tybru, a potem jeść ją spoglądając na rzekę z mojego nędznego lokum na Awentynie [...]. Chciałem usłyszeć ryk, który przetacza się ponad torem podczas końskich wyścigów w Circus Maximus. Chciałem spektakularnych skandali i przestępstw na gigantyczną skalę. Chciałem, by zdumiewały mnie ich rozmiary i nikczemność. Chciałem wrócić do domu ${ }^{61}$.

Raz jeszcze obcość pozwala zdefiniować tu rzymskość. Falko tęskni do skali Rzymu we wszystkich aspektach: od „zaskakującej wysokości tandetnych kamienic” po „zapach świeżego oregano przebijający przez nieznośny fetor targu rybnego" 62 .

Dla wszystkich bohaterów rzymskich kryminałów to Rzym jest centrum ich świata i poprzez jego pryzmat oglądają wszystkie miejsca, w które pchnie ich los. Gordianus trafia do Aleksandrii parokrotnie i ją podziwia, ale oczywiście nie potrafi nie porównać jej z własnym miastem:

Rzym to labirynt ciasno stłoczonych sklepów, kamienic, świątyń i pałacom podobnych willi budowanych, zda się, jedne na drugich, bez żadnego poczucia proporcji; niegdysiejsza wioska rozrastająca się w niekontrolowany sposób, tętniąca życiem i tchnąca butną witalnością. Aleksandria jest miastem szerokich, prostych jak z łuku strzelił ulic, wielkich placów, wspaniałych świątyń, imponujących fontann i ustronnych ogrodów. Precyzja greckiej architektury wytwarza aurę starego bogactwa i zamiłowania do porządku. [...] ale z drugiej strony żar egipskiego słońca wprowadza rozleniwienie; właśnie to napięcie między dwoma biegunami, dyscypliną i ospałością, nadaje miastu jego jedyny w swoim rodzaju, często zdumiewający przybysza charakter. Dla Rzymianina jest ono raczej senne i pełne samozadowolenia, a przy tym zbyt wyrafinowane, aż do zmęczenia

\footnotetext{
60 L. Davis, Ostatni akt w Palmirze, s. 422.

61 Tamże, s. 348.

62 L. Davis, Wykute w brazie, s. 501.
} 
życiem i światem, niczym kurtyzana, której jest już wszystko jedno, co sobie kto o niej pomyśli. Aleksandryjczykowi Rzym musi się wydawać przesadnie wulgarny, pełen [...] architektonicznej pstrokacizny i uliczek przyprawiających o klaustrofobię ${ }^{63}$.

To piękne wschodnie miasto jest zatem dla Gordianusa przede wszystkim nie-Rzymem. Raz jeszcze chaotyczna witalność miasta nad Tybrem okazuje się atrakcyjniejsza niż idealny estetyczny porządek hellenistycznego miasta.

Jak wszystkie odmiany wyjściowej konwencji, i kryminał historyczny jest gatunkiem silnie związanym z przestrzenno-antropologicznym porządkiem miasta. Zatem to po zaułkach i wąskich uliczkach miasta, które już przeczuwa swoją wieczność, krążą Decjusz, Gordianus i Falko starając się przeniknąć - czasami mordercze - rzymskie sekrety. W przywołanych tu powieściach pojawia się Rzym jako miejsce zamieszek, ulicznych porachunków zwolenników przeciwnych frakcji politycznych, machlojek budowlanych, wielce podejrzanego handlu nieruchomościami, miasto willi i czynszowych kamienic z przeciekającymi dachami, miasto "dymu i ognia”. Jednak miejska przestrzeń - doświadczana w łańcuchu zapośredniczeń - pełni tu funkcję klasycznej mise-en-scène - jak się wydaje całkowicie podporządkowanej konwencji gatunkowej. Przestrzeń staje się tu nie tylko tłem, ale i po części współsprawcą rozmaitych zbrodniczych przedsięwzięć mieszkańców tego miasta-świata, nie zaś - jak choćby w powieściach Agaty Christie - tworzy cozzy ${ }^{64}$, sielski kontrapunkt dla morderczych instynktów jego obywateli.

Paweł Kaczyński podsumowując swoje uwagi o kryminale historycznym, pisze: „ta historyczna odmiana literatury kryminalnej staje się atrakcyjniejszą dla wielu czytelników wersją powieści historycznej, odświeżając zarówno jej formułę, jak i formułę kryminału" ${ }^{\prime 65}$. Aczkolwiek mowa tu o subgatunku powieści kryminalnej - zatem o formie, której wszystkie elementy podporządkowane są atrakcyjności intrygi, konwencja ta obciążona jest też ambicjami poznawczymi powieści historycznej. Czego zatem czytelnik dowiaduje się o SPQR schyłku republiki i z czasów Wespazjana z rzymskich kryminałów? Przede wszystkim otrzymujemy tu żywy obraz metropolii, chaotycznej, eklektycznej i witalnej zarazem, świata w stanie terytorialnej ekspansji. Jeżeli uznać za słuszne konstatacje Ryszarda Koziołka, będące nawiązaniem do znanego tekstu Davida Lowenthala ${ }^{66}$, iż ",czas wytwarza obcość, różnicę,

\footnotetext{
63 S. Saylor, Werdykt Cezara, w: tegoż, Ostatnie sprawy Gordianusa, s. 108.

64 Zob. M. Czubaj, Etnolog w Mieście Grzechu, s. 38.

65 P. Kaczyński, Kryminał historyczny - próba poetyki, s. 207.

66 Zob. D. Lowenthal, Przeszłość to obcy kraj, przeł. I. Grudzińska-Gross i M. Tański, „Res Publica" 1991, nr 3.
} 
niezrozumiałość, które trudno przezwyciężyć" ${ }^{67}$, to ten obraz wydaje się być szalenie swojski i zrozumiały. Dzieje się tak zapewne dlatego, że obcość „rzymskości” została już dawno oswojona w rozlicznych teatralizacjach ${ }^{68}$, głównie w obszarze kultury popularnej. I dlatego raczej z dreszczem rozpoznania niż obcości krążymy wraz z rzymskimi detektywami po obskurnych i wspaniałych zaułkach miasta, śledząc, co się dzieje "sub rosa".

\section{Bibliografia}

Beard Mary, SPQR. Historia starożytnego Rzymu, przeł. N. Radomski, Poznań: Dom Wydawniczy „Rebis”, 2017.

Bradshaw Smith Donna, Bruce Alexander: Sir Henry Fielding and Blind Justice, w: The Detective as Historian: History and Art in Historical Crime Fiction, ed. R.B. Browne and L.A. Kreiser Jr, Bowling Green: Bowling Green State University Popular Press, 2000, s. 175-185.

Czubaj Mariusz, Etnolog w Mieście Grzechu. Powieść kryminalna jako świadectwo antropologiczne, Gdańsk: Oficynka, 2010.

The Detective as Historian: History and Art in Historical Crime Fiction, ed. R.B. Browne \& L.A. Kreiser, Jr, Bowling Green: Bowling Green State University Popular Press, 2000.

Dominas Konrad, Antyk w kryminale, kryminat w antyku. Steven Saylor i recepcja literatury antycznej, w: Literatura kryminalna. Na tropie źródeł, red. A Gemra, Kraków: EMG 2015, s. 221-241.

Izdebska Agnieszka, hasło kryminał historyczny, „Zagadnienia Rodzajów Literackich" 2016, t. 59, z. 4, s. 137-143.

Kaczyński Paweł, Kryminał historyczny - próba poetyki, w: Literatura kryminalna. Śledztwo w sprawie gatunków, red. A. Gemra, Kraków: EMG, 2014, s. 191-209.

Koziołek Ryszard, Dobrze się myśli literatura, Wołowiec: Wydawnictwo Czarne, 2016.

Kraska Mariusz, Prosta sztuka zabijania. Figury czytania kryminału, Gdańsk: Fundacja Terytoria Książki, 2013.

Pascal C. Bennett, October Horse, „Harvard Studies in Classical Philology” 1981 (85), s. 261-291.

Salamone Frank A., Maan Meyers: The Saga of Dutchman, w: The Detective as Historian: History and Art in Historical Crime Fiction, ed. R.B. Browne and L.A. Kreiser Jr, Bowling Green: Bowling Green State University Popular Press, 2000, s. 169-174. Winks Robin W., Preface, w: The Detective as Historian: History and Art in Historical Crime Fiction, ed. R.B. Browne i L.A. Kreiser, Jr, Bowling Green: Bowling Green State University Popular Press, 2000, s. ix-x.

${ }^{67}$ R. Koziołek, Kto jeszcze umrze przez Robespierre'a, w: tegoż, Dobrze się myśli literatura, Wołowiec 2016, s. 107.

68 Trudno raz jeszcze nie zgodzić się tu z Koziołkiem, który pisze: „Fikcja historyczna to zawsze teatralizacja trupa dla ciągle nowej widowni" [tamże]. 


\section{"Rome is Everywhere": \\ Space in Historical Crime Fiction by Steven Saylor, John Maddox Roberts and Lindsey Davis}

\section{Summary}

The article evaluates the spatial aspects of historical crime novels located in Ancient Rome. In particular, it demonstrates the image of the Roman Empire and the functions of space. This classic mise-en-scène is completely subordinated to the genre convention. The space becomes not only a background but also a component of various criminal actions. Unlike in Agatha Christie's novels, it does not create an idyllic counterpoint to the murderous instincts of Roman citizens. The article concentrates on the form of historical crime fiction, in which all elements are subordinated to the attractiveness of intrigue. However, it also refers to the cognitive ambitions of the historical novel. So the question is what the reader learns about the $S P Q R$ of the declining Republic or about Vespasian Rome. First and foremost, it is the vivid image of the metropolis - chaotic, eclectic and vital. It is the world in a state of territorial expansion. Contrary to the assumption shared by Ryszard Koziołek with David Lowenthal that the past is the domain of otherness and that the difference generates incomprehensibility, this picture seems to be extremely familiar and understandable. This is probably due to the fact that the foreignness of "Romanity" has been familiarized in popular culture.

Keywords: space, historical crime fiction, Ancient Rome, Steven Saylor, John M. Roberts, Lindsey Davis 